\title{
ROSA LUXEMBURG: REFORMISMO, DEMOCRACIA Y CONCIENCIA REVOLUCIONARIA
}

\section{ROSA LUXEMBURG: REFORMISM, DEMOCRACY AND REVOLUTIONARY CONSCIOUSNESS}

\section{Paloma Martínez Matías}

Universidad Complutense de Madrid

palomamartinezm@filos.ucm.es

Palabras clave: capitalismo, Marx, socialdemocracia, revolución, populismo, República de Weimar Keywords: capitalism, Marx, social democracy, revolution, populism, Weimar Republic

Resumen: Con el objetivo de mostrar la relevancia y actualidad de la obra teórica de Rosa Luxemburg, el artículo analiza tres de sus temáticas fundamentales. En primer lugar, su crítica a la deriva reformista de la socialdemocracia contra su original intención revolucionaria, confirmada en su validez por la evolución del capitalismo. En conexión con ello, su tesis de que la posibilidad de la realización de la democracia se encuentra estrictamente vinculada al proyecto revolucionario. Y, por último, su reivindicación de que la existencia de dicho proyecto depende de que el proletariado adquiera un conocimiento teórico sobre el funcionamiento del capitalismo que debe serle transmitido por el partido revolucionario.

Abstract: With the objective of highlighting the relevance and topicality of the theoretical work of Rosa Luxemburg, this article analyzes three of her fundamental themes. Firstly, her criticism of the reformist drift of social democracy against its original revolutionary intention, confirmed in its validity by the evolution of capitalism. In connection with this, her thesis concerning the possibility of the realization of democracy is strictly linked to the revolutionary project. Finally, her assertion that the existence of such a project depends on the proletariat acquiring a theoretical knowledge about the inner workings of capitalism that must be transmitted to them by the revolutionary party. 


\section{Introducción}

En el artículo que en 1966 dedicara a la figura de Rosa Luxemburg con motivo de la publicación de una extensa biografía sobre esta singular teórica y militante revolucionaria, Hannah Arendt sostiene que su muerte, calificada sin paliativos de asesinato al amparo de la socialdemocracia en el poder, marcaría un antes y un después en la historia alemana al convertirse en un punto de no retorno para la izquierda política ${ }^{1}$. En línea con esta premisa, los estudios sobre el pensamiento y la actividad política de Rosa Luxemburg -dos dimensiones que en su caso no cabe aislar sin menoscabo de la inteligibilidad de sus textos- no han dejado de suscitar entre sus lectores la pregunta por la posibilidad de que, de no haber tenido lugar su asesinato, la historia hubiera sido otra distinta de la efectivamente acaecida, y otros los hechos que habrían perfilado el trayecto hacia un presente entonces sometido a la incógnita, para sugerir una respuesta tanto afirmativa como negativa a este interrogante. Pues, ciertamente, existen razones que permiten decantarse por cada una de ambas opciones sin que resulte fácil discernir cuál de ellas se ve avalada por mejores y más convincentes argumentos.

1. Se trata del artículo que Hannah Arendt publicara en 1966 en The New York Review of Books con el título "Rosa Luxemburg: 1871-1919", posteriormente incluido en el volumen Men in Dark Times (New York, 1968; hay traducción al castellano de C. Ferrari, Hombres en tiempos de oscuridad, Gedisa, Barcelona, 1990, pp. 4366), y que se propone a modo de reseña de la biografía de Peter Nettle Rosa Luxemburg (Oxford University Press, London, 1966; también hay traducción al castellano de F. Blanco, Rosa Luxemburgo, Era, México, 1974).
En lo que respecta a su labor teórica, que se asienta decididamente sobre la filosofía de Marx al tiempo que desarrolla aspectos económicos y políticos clave de la misma, la muerte de Rosa Luxemburg representa el fin del intento tal vez más comprometido de defender el objetivo revolucionario que en sus inicios vertebrara el programa político de la socialdemocracia, así como de pensar los requisitos que harían viable el proyecto emancipatorio de la revolución. Un proyecto que, como es sabido, localizaba en el desmontaje del modo de producción capitalista el único camino capaz de dar término a su más viva contradicción, a saber, que el imparable progreso tecnológico que éste genera no haya conducido a la liberación del ser humano de la esclavitud del trabajo, sentido como un factor de creciente alienación bajo la percepción de tal paradoja. Tras décadas de innovaciones técnicas sin duda imprevisibles a comienzos del siglo XX, la actual persistencia y agudización de esta contradicción bien podría indicar que algo valioso se perdió no sólo con la caída de toda aspiración revolucionaria del horizonte político, sino también y, quizá ante todo, con la desaparición de aquella figura intelectual que con mayor seriedad trató de reflexionar con Marx y más allá de Marx sobre la necesidad de la revolución y las condiciones de su eventual desenvolvimiento. Sin embargo, lejos de alcanzar un reconocimiento acorde a su altura teórica, las ideas de Rosa Luxemburg nunca fueron suficientemente comprendidas y tuvieron una posición marginal en el seno de la socialdemocracia alemana². De ahí

2. Cf. Arendt, H., Hombres en tiempos de oscuridad, op. cit., p. 44. Tal incomprensión se debería, entre otros factores, a la progresiva deriva del Partido Socialdemócrata Alemán, a partir de la última década del siglo XIX y en contra de los principios establecidos en el Congreso de Erfurt 
que la tesis de que la temprana interrupción de la producción intelectual de Rosa Luxemburg habría consignado el destino mismo de la socialdemocracia no haga en realidad justicia a su escasa influencia dentro de su propio partido.

Algo similar cabe decir sobre la incidencia de su pensamiento en la izquierda revolucionaria desgajada a partir de 1914 del Partido Socialdemócrata tras su inesperado apoyo a la participación de Alemania en la Primera Guerra Mundial. En los últimos meses de existencia de la Liga Espartaco la postura de Luxemburg quedó en minoría y así se mantuvo en el marco del recién fundado Partido Comunista Alemán, al que se adhirió sin genuina convicción y básicamente impulsada por la coyuntura socio-política ${ }^{3}$. Conviene igualmente recordar que, aun cuando su pensamiento habría dibujado una visión alternativa a la de Lenin en lo que concierne a la naturaleza del proyecto revolucionario, fue la concepción bolchevique la que finalmente se impuso, dando paso a un complejo curso de acontecimientos que desembocarían en lo que, en última

de 1891, hacia posiciones cada vez más alejadas de la teoría de Marx y de su visión revolucionaria de la acción política, ambas radicalmente defendidas por Rosa Luxemburg. En este proceso destaca la centralidad que para la dirección del Partido adquiriría la táctica parlamentarista, guiada por el objetivo de recabar el máximo apoyo electoral de las masas y que conduciría en función de él a la renuncia al cumplimiento del programa de Erfurt. Sobre la difícil posición de Luxemburg en el Partido Socialdemócrata Alemán desde su ingreso en el mismo en 1898, cf. Gómez Llorente, L., Rosa Luxemburgo y la socialdemocracia alemana, Cuadernos para el diálogo, Madrid, 1975, p. 42 y ss., así como Nettle, P., Rosa Luxemburgo, op. cit., p. 105 y ss.

3. Cf. Nettle, P., Rosa Luxemburg, op. cit., p. 542 y ss. instancia, parece sensato valorar como el fracaso de toda acción revolucionaria históricamente constatable y la subsiguiente renuncia a la propia idea de la revolución. Pese a ello, probablemente Hannah Arendt acierte al apuntar que quienes abandonaron el Partido Socialdemócrata para unirse al Partido Comunista, pero también vivieron con éste una amarga decepción, eludieron toda tentación de regresar a las filas de la socialdemocracia: semejante retorno hubiera significado un gesto de perdón hacia el asesinato de Luxemburg que en modo alguno estaban dispuestos a otorgar ${ }^{4}$. Con su muerte la izquierda política quedaría definitivamente escindida y enfrentada, y no pocas decisiones del Partido Comunista Alemán en los años posteriores, algunas de efectos nefastos para la recién instituida República de Weimar ${ }^{5}$, tendrían su origen en su creciente animadversión hacia el Partido Socialdemócrata por su presunta traición a la causa izquierdista.

Pero más allá de las implicaciones que se seguirían de su muerte, así como de la pregunta por la posible alteración del curso de la historia si ésta no hubiera ocurrido, la desaparición de Rosa Luxemburg no difuminó la condición de figura incómoda que ya ostentara en vida tanto para la socialdemocracia como para la facción comunista, saldada por ambas instancias con un juicio taxativo sobre el

4. Cf. Arendt, H., Hombres en tiempos de oscuridad, op. cit., p. 46.

5. Sobre el papel desestabilizador del Partido Comunista Alemán durante la República de Weimar y su recurrente oposición al Partido Socialdemócrata, agudizada a partir de 1928 y que le llevaría a adoptar una actitud ambivalente frente al Partido Nacionalsocialista, cf. Klein, C., De los espartaquistas al nazismo: la República de Weimar, Edicions 62, Barcelona, 1970, pp. 5152 y 91 y ss. 
flagrante error de su posición que durante años relegaría su obra al más inmerecido de los olvidos ${ }^{6}$. Algo de esa incomodidad se experimenta en la actualidad con la lectura de sus textos, pese a que ahora la sensación brota de un lugar diferente al que explica la provocada en su época: su encendida reivindicación de la vía revolucionaria en indisoluble alianza con el programa socialdemócrata se presenta a día de hoy envuelta en el halo de lo por completo extemporáneo, de lo radicalmente intempestivo, como si en ella espejeara un sueño lejano y difuso en la distancia cuya falta de vigencia impide su reactivación incluso como simple idea -0 ensoñación utópica- sobre la que debatir y reflexionar. En ello confluyen no sólo el conocimiento de las tenebrosas consecuencias de las revoluciones acometidas, sino también el hecho de que, como ha señalado gráficamente Slavoj Zizek, en el siglo XXI se concede mayor plausibilidad a la hipótesis del potencial cese de toda forma de vida sobre la faz de la tierra por un inminente colapso de la naturaleza que a la del fin del régimen de producción capitalista7. Por un lado, éste ha logrado superar y salir fortalecido de todas sus crisis, afianzando y expandiendo en cada ocasión sus dinámicas de actuación hasta llegar a sobrevolar, sin modificaciones significativas en su funcionamiento, el diagnóstico sobre la urgencia de una "refundación" del capitalismo pronunciado a raíz de su última crisis. Pero también la evidencia de que el capitalismo moldea las conciencias y forja las subjetividades contemporáneas, volviéndolas proclives a

6. Cf. Basso, L., El pensamiento político de Rosa Luxemburg, Península, Barcelona, 1976, p. 10 y ss.

7. Cf. Zizek, S., "El espectro de la ideología", en Ideología. Un mapa de la cuestión, FCE, Buenos Aires, 2003, p. 7. la aceptación de la precariedad, el consentimiento de una explotación no intuida como tal y la lucha competitiva desprendida de toda solidaridad de clase, coarta de antemano la mera imaginación de un movimiento de masas, o siquiera de una organización política, penetrados por la voluntad de emprender una lucha colectiva que persiguiera instaurar otro modo de producción ajeno a la lógica de la valorización del valor. Entre otras razones, porque tras largas décadas de imperio del capitalismo, y a la vista de las experiencias fallidas de aquellos Estados que, en contra de los análisis marxianos, ensayaron formas productivas no capitalistas en medio de su hegemonía internacional, tampoco parece quedar ya al alcance de esas subjetividades, articuladas a la medida del dominio del capital, la facultad de imaginar tales modos alternativos de producción.

Pero que la revolución no sea hoy en día posible, e incluso que tal vez nunca lo fuera en el sentido en el que, partiendo de Marx, Rosa Luxemburg la concibiera -y a lo largo de este ensayo habrán de salir a la luz algunos de los motivos que subyacen a tal imposibilidad- no quiere decir que sus reflexiones en torno a ella y a la problemática que entraña estén de antemano exentas de validez para el debate político contemporáneo. Antes bien, los textos de Luxemburg inciden con inusitada lucidez sobre cuestiones relativas a la evolución del capitalismo y a la función de la política frente a sus perennes contradicciones que, también en su vinculación al desacreditado propósito de la revolución, ponen de manifiesto la relevancia de su pensamiento para entender la configuración del mundo actual. Entre tales cuestiones, destaca su crítica a la deriva reformista de la socialdemocracia, convertida 
tras su muerte en el sello de identidad de esta tendencia política, que atraviesa desde hace tiempo una permanente crisis tanto por su debilidad correctiva frente a las exigencias de la economía capitalista como por la preeminencia que a partir de los años setenta adquiriera el ideario neoliberal en su pretensión -no siempre confesada- de ajustar la construcción de las sociedades y subjetividades contemporáneas a tales exigencias. Asimismo, es digna de atención la obstinada defensa de Luxemburg de las formas democráticas en la realización de la empresa revolucionaria, basada en una comprensión de la noción de democracia cuyo rigor ofrece claves esenciales para juzgar hasta qué punto los Estados democráticos materialmente existentes han conquistado el ideal democrático que recurrentemente enarbolan frente a otros modos de organización política. Por último, su enfoque sobre la misión de los partidos políticos de izquierdas diverge radicalmente de los planteamientos ideológicos de las fuerzas populistas que habrían de abocar al término de la República de Weimar, abriendo una perspectiva igualmente crítica ante las que desde fecha reciente emergen a uno y otro lado del espectro político. A la dilucidación de estas tres temáticas se dedicará el trayecto que aquí comienza.

\section{La impotencia de la socialdemocracia reformista}

La actualidad de la crítica de Rosa Luxemburg a la concepción reformista que, contra su original vocación revolucionaria, acabaría prevaleciendo en el Partido Socialdemócrata Alemán se torna netamente visible a la luz del examen de la actuación de los partidos de filiación socialdemócrata ante el desarrollo del capitalismo desde el final de la Segunda Guerra Mundial hasta el presente. Pues los elementos que sustentan esa crítica proporcionan una explicación tan clara como incontestable sobre las razones de fondo por las que los mecanismos de reforma parlamentaria aplicados por los gobiernos asociados a la izquierda política no han conseguido alterar en lo sustancial la relación capital-trabajo, ni han contribuido a una mejora de las condiciones de vida de la población trabajadora proporcional a los extraordinarios incrementos de la productividad ocasionados por las revoluciones e innovaciones tecnológicas.

La transformación reformista de la socialdemocracia alemana, calificada por Luxemburg de desviación y asimilada al oportunismo político, se liga en el texto de 1900 ¿Reforma social o revolución? a la producción intelectual de Eduard Bernstein, quien había abogado por ella en una serie de artículos publicados en el periódico Neue Zeit entre 1897 y 1898 y en el libro Las premisas del socialismo y las tareas de la socialdemocracia ${ }^{3}$. A raíz del período de auge económico y expansión capitalista que Alemania vive en ese momento ${ }^{9}$,

8. Bernstein, E., Die Voraussetzungen des Sozialismus und die Aufgaben der Sozialdemokratie, Dietz, Stuttgart, 1899. Acerca de la dualidad del Partido Socialdemócrata Alemán en torno a la cuestión del reformismo, cuyo rechazo teórico a las tesis de Bernstein convivía con la puesta en práctica de medidas netamente reformistas, cf. Gómez Llorente, L., Rosa Luxemburgo y la socialdemocracia alemana, op. cit., pp. 44-45, así como Trías Vejarano, J., "Rosa Luxemburg y los debates en la II Internacional”, en J. Trías y M. Monereo (eds.), Rosa Luxemburg. Actualidad y clasicismo, El Viejo Topo-FIM, 2001, pp. 23-24.

9. De hecho, se trata de un período de expansión generalizada del capitalismo en los principales países occidentales que se extiende entre 1893 y 
Bernstein proclama que la evolución del capitalismo muestra una capacidad de adaptación de este régimen productivo que, además de permitir su subsistencia a largo plazo, se haría patente en la tendencia a la desaparición de sus crisis, en el fortalecimiento de las clases medias y en los avances en la situación económico-política del proletariado como resultado de la lucha sindical. Puesto que esa capacidad adaptativa sería para Bernstein signo de la atenuación y paulatina eliminación de las contradicciones internas del capitalismo, de ella extrae la conclusión de la pertinencia de redefinir los objetivos de la socialdemocracia: en vez de luchar por la toma del poder político con el fin de liquidar este sistema productivo, la socialdemocracia debía proceder por la vía parlamentaria a una serie de reformas que culminaran en la implantación pacífica del socialismo.

Contra esta posición, Luxemburg se adhiere a la tesis marxiana del carácter intrínsecamente contradictorio del capitalismo para sostener que, lejos de tratarse -como Bernstein afirma- de meros accidentes o perturbaciones de este modo de producción subsanables a través de la acción política, las crisis que se siguen de sus contradicciones constituyen más bien un efecto inevitable de su dinámica interna: en ellas se encuentra el único medio por el que el capitalismo «resuelve periódicamente el conflicto existente entre el ilimitado potencial expansivo de la producción y los estrechos límites del mercado» ${ }^{10}$, a

1913 a consecuencia de la aplicación de políticas imperialistas y de la revolución tecnológica que implicó la introducción de la electricidad, dando lugar a una significativa elevación de la tasa de plusvalía. Cf. Mandel, E., Las ondas largas del desarrollo capitalista, Siglo XXI, Madrid, 1986, p. 20.

10. Luxemburg, R., "Socialreform oder Revolution?", en Gesammelte Werke. Band I/1, Dietz, Berlin, 1974, p. 406. la vez que pone freno a la "ley de la tendencia decreciente de la tasa de ganancia" formulada por Marx, consecuencia del progresivo reemplazo de la fuerza de trabajo humano por maquinaria e innovaciones tecnológicas al que conduce el gradual aumento de los niveles de productividad característico de la producción capitalista ${ }^{11}$. En el mecanismo destructivo de las crisis, cuyas aciagas repercusiones sociales afectan ante todo a la clase trabajadora, Luxemburg localiza por tanto un "fenómeno orgánico" de la economía capitalista inextirpable para toda acción política que renuncie a su abolición. De ahí que el escrito ¿Reforma social o revolución?, en el que su autora se erige en portavoz de los principios esenciales de la socialdemocracia, intente refutar su desviación reformista aportando argumentos que avalarían la necesidad de preservar la perspectiva revolucionaria que presidió su nacimiento.

Los avatares de la historia del capitalismo han confirmado la interpretación de Luxemburg sobre lo que Bernstein considerara formas de adaptación del capitalismo que favorecerían la futura supresión de sus crisis: en ellos detecta factores

11. Cf. ibid. La "ley de la tendencia decreciente de la tasa de ganancia" revela para Marx la contradicción tal vez más grave del modo de producción capitalista: en ella se hace patente un decrecimiento tendencial de la plusvalía obtenida en el proceso productivo, provocado por la menor intervención en él de la fuerza de trabajo humano, que dificulta cada vez en mayor medida la valorización del capital invertido pese a los continuos incrementos de la productividad. Para esta cuestión, cf. Marx, K., Das Kapital. Kritik der politischen Ökonomie. Buch III: Der gesamtprozeß der kapitalistischen Produktion, en Karl Marx - Friedrich Engels. Werke, Band 25, hrsg. vom Institut für Marxismus-Leninismus beim ZK der SED, Dietz, Berlín, 1973, pp. 221-278. 
que, por el contrario, apuntalan su surgimiento por agudizar sus contradicciones. Así, Luxemburg rebate la idea de que el crédito, al incrementar la producción y el intercambio de mercancías, facilita la superación de los obstáculos que periódicamente enfrenta el sistema capitalista: por un lado, en ese mismo aumento de la producción se sitúa el origen de las crisis de sobreproducción que sobrevienen una vez se rebasa la capacidad de absorción del mercado, crisis que al mismo tiempo se acentúan por la rápida contracción del crédito al menor indicio de estancamiento y la consiguiente caída del intercambio de mercancías; a ello se suma el que, al estimular la inversión y la actividad especulativa, más inclinadas al riesgo cuando se utilizan capitales ajenos, el crédito fluidifica los engranajes de la economía capitalista, disolviendo sus rigideces y acelerando el acaecimiento de las crisis provocadas por la colisión de sus fuerzas contradictorias. Si una segunda forma de adaptación del capitalismo reside, según Bernstein, en la creación de alianzas empresariales que contendrían la anarquía generada por la concurrencia capitalista, a ello Luxemburg objeta que si bien tales alianzas rebajan la competencia dentro de una determinada rama de la producción, su participación en los mercados extranjeros, promovida por sus mayores beneficios, acrecienta sin embargo la competencia internacional y la anarquía del mercado mundial. Por ello, las alianzas empresariales no sólo agravan la contradicción entre el capital y el trabajo al elevar la fuerza de presión del capital organizado sobre el proletariado, sino que también agudizan la contradicción -tan notoria en el mundo globalizado actual- entre el alcance internacional del capitalismo y la constitución nacional de los Estados políticos.
Luxemburg niega asimismo la posibilidad de una implantación gradual del socialismo por medio de los cauces indicados por los reformistas, a saber, la lucha sindical y política por las reformas sociales y la democratización del Estado. Contra la expectativa de que los sindicatos acaben con la explotación laboral, insiste en que su margen de maniobra se reduce a tratar de atenuarla y que su tarea sería semejante a la de un "trabajo de Sísifo"12, ya que sus logros no representan más que conquistas provisionales siempre sujetas a constantes retrocesos. Ello respondería a la falta de influencia de los sindicatos sobre las variables que prescriben el precio de la fuerza de trabajo -fundamentalmente la demanda y la oferta de la misma-, así como a su impotencia frente a la dinámica por la que el continuo incremento de la productividad intrínseco a la maquinaria capitalista implica una indefectible elevación de la explotación laboral -al aumentar lo que Marx Ilamara la "plusvalía relativa"-, a menudo encubierta por coyunturales mejoras en el nivel de vida de los trabajadores ${ }^{13}$. Por lo demás, a partir de su precisa comprensión de Ios análisis marxianos sobre el funcionamiento del capitalismo, Luxemburg augura las crecientes dificultades de la lucha sindical -igualmente corroboradas por el devenir histórico- a mayor grado de madurez de su desarrollo: entre los factores contrarrestantes de la tendencia a la caída de la tasa de ganancia, destacan las reducciones salariales y la prolongación de la jornada de trabajo ${ }^{14}$, medidas que

12. Cf. Luxemburg, R., "Socialreform oder Revolution?", op. cit., p. 420.

\section{Cf. ibid., pp. 419-420.}

14. Cf. Marx, K., Das Kapital. Kritik der politischen Ökonomie. Buch III: Der gesamtprozeß der kapitalistischen Produktion, op. cit., pp. 242-245. 
el capital nunca deja de imponer sobre la clase trabajadora al ver peligrar sus beneficios y que ésta termina por aceptar ante la amenaza del desempleo. Pero Luxemburg también subraya el componente reaccionario que envuelve la política sindical: dado que ésta se opone a los avances técnicos, que expulsan a los trabajadores del mercado laboral y empeoran sus condiciones de trabajo, con ello vela únicamente por el interés del trabajador individual desatendiendo los intereses del conjunto de la clase obrera, cuya eventual emancipación de la esclavitud del trabajo se hallaría estrictamente ligada al progreso tecnológico ${ }^{15}$.

En lo que respecta a la lucha política, Luxemburg acusa un salto imposible entre las reformas sociales que se concretan en leyes de protección de los trabajadores y la instauración de un nuevo orden que,

15. Como se ha comentado, el desarrollo del capitalismo conduce, según Marx, a una paulatina disminución de la intervención del tiempo de trabajo humano en la producción a consecuencia de su dependencia «del estado general de la ciencia y del progreso de la tecnología, o de la aplicación de esta ciencia a la producción» (Grundrisse der Kritik der Politischen Ökonomie (Rohentwurf) 1857-1858, Marx-Engels-Institut Moskau, Berlín, Dietz, 1974, p. 592). En esa sustitución del hombre por la máquina, resultante de los avances tecnológicos, residiría la condición de posibilidad del tránsito del orden capitalista al socialismo, cuyo pilar productivo fundamental no sería ya la explotación del tiempo de trabajo del ser humano, sino la apropiación por parte de éste «de su propia fuerza productiva general, su comprensión de la naturaleza y su dominio de la misma gracias a su existencia como cuerpo social» Ibid., p. 593. Lo cual significa: la apropiación por parte del conjunto de la sociedad de aquellos medios productivos cuyo desarrollo tecnológico permite liberar al hombre del trabajo y que, bajo el régimen de producción capitalista, sólo contribuyen a la esclavitud y precariedad de la mayoría de sus miembros. gracias a la propiedad colectiva y el control social de los medios de producción, anulara de raíz los mecanismos de expropiación del trabajo imperantes bajo el régimen capitalista. De entrada, el tránsito de la sociedad feudal a la capitalista supone a su juicio un fortalecimiento del derecho de propiedad, concebido en esta última como un derecho de las personas sobre las cosas determinado por relaciones de intercambio ${ }^{16}$. Sobre esta base, la organización jurídica de la sociedad capitalista entiende la compra-venta de la fuerza de trabajo como una relación en la que dos agentes, enfrentados como iguales con sus respectivas mercancías, establecen libremente un contrato de intercambio. La explotación inherente al trabajo asalariado no comparece entonces propiamente como tal en esta sociedad, sino que se presenta como el resultado de un acuerdo entre contratantes libres e iguales. Así se sanciona legalmente, enfatiza Luxemburg, el que el derecho de propiedad se convierta no ya en el derecho sobre ciertos objetos o sobre el producto del propio trabajo, sino también en el derecho a la apropiación del trabajo ajeno, sin que ello involucre en ningún caso la quiebra de la situación de igualdad y libertad jurídicas de quienes participan en el intercambio. Esto se traduce en la ausencia de expresión en el ordenamiento jurídico burgués de la dominación de la burguesía sobre la clase trabajadora: a diferencia de la sociedad feudal, es la carencia de medios de producción y no la ley la que obliga al proletariado a someterse a la explotación capitalista, de manera que el dominio burgués procede de relaciones materiales o económicas que no se reflejan en fórmulas legales. En este sentido, escribe Luxemburg, "no hay ley

16. Cf. Luxemburg, R., "Socialreform oder Revolution?”, op. cit., pp. 392-393. 
en el mundo que, en el marco de la sociedad burguesa, pueda darle al proletariado esos medios de producción, ya que no fue la ley la que le privó de ellos, sino el desarrollo económico» ${ }^{17}$. Y a partir de esta idea enuncia una tajante conclusión: puesto que las relaciones de dominio no se introdujeron en la sociedad capitalista a través de las leyes ni se plasman en su sistema jurídico, ninguna reforma legal realizada en el seno de la sociedad burguesa traerá consigo la futura liquidación de tales relaciones.

En conexión con esta cuestión, Luxemburg apela a la dualidad del modelo de Estado que deriva del triunfo político de la burguesía ya señalada por Marx. Tanto la continua ampliación de las funciones del Estado que requiere el desarrollo del capitalismo, en parte orientadas a la regulación y control de la vida económica, como la incorporación burguesa de las formas democráticas, dan lugar a una transformación del Estado por la cual éste alberga el germen de su potencial fusión con el todo social, es decir, de su equivalencia con el conjunto de la sociedad. Sin embargo, al mismo tiempo, el Estado de la sociedad capitalista emerge como representante de su clase dominante y del modo de producción que ésta regenta, por lo que su injerencia en la vida económica se encamina principalmente a satisfacer los imperativos que entraña su funcionamiento, indisolublemente vinculados a los intereses de la burguesía. De tal ambivalencia se desprende para Luxemburg que «las reformas sociales encontrarán sus límites en el interés del capital» ${ }^{18}$. Esto significa que el "Estado burgués" sólo actúa en beneficio del progreso económico

17. Ibid., p. 430.

18. Ibid., p. 392. del todo social cuando éste confluye con el de la burguesía como clase dominante, mientras que en el momento en que los intereses del capital se distancian de los principios que fomentan el bienestar social, no vacila en aplicar medidas contrarias a éste último en provecho de la burguesía. De ello darían noticia las políticas arancelarias practicadas por los Estados europeos de la época y su apoyo generalizado al militarismo, en el que Luxemburg anticipa, ya en este texto de 1900, el probable conflicto entre naciones que años más tarde se materializaría en la Primera Guerra Mundial ${ }^{19}$ : pese a que ambas estrategias políticas habrían favorecido inicialmente el desarrollo económico, su posterior pervivencia se justifica exclusivamente por la satisfacción de los intereses de la burguesía -que se valdría de ellas para la protección de sus empresas, la inversión de capitales y la dominación de la clase obrera- en detrimento del progreso social. A ello se agrega el que el carácter de clase del Estado en la sociedad capitalista impide que el ejercicio efectivo de la democracia -lo que Luxemburg Ilama en sus textos el "parlamentarismo burgués"proteja los intereses del conjunto de la sociedad: por más que las instituciones procedan formalmente en ella conforme a la dinámica democrática, su construcción obedecería en su realidad concreta a la voluntad de asegurar el dominio de clase de la burguesía. Tal voluntad quedaría probada en el hecho de que «en cuanto la democracia muestra una tendencia a negar su carácter de clase y a convertirse en un instrumento de los intereses reales de las masas populares, la burguesía y sus representantes en el aparato del Estado sacrifican las formas democráticas ${ }^{20}$. Se-

19. Cf. ibid., pp. 395-97.

20. Ibid., p. 399. 
gún Luxemburg, el propio Bernstein habría reconocido esta actitud reaccionaria de la burguesía e identificado en ella una respuesta de temor ante el ascenso del movimiento obrero. Por eso considerará contradictorio su consejo al proletariado de desistir de sus aspiraciones socialistas para preservar las formas democráticas y facilitar sus avances ${ }^{21}$ : la predisposición de la burguesía a abandonar la democracia una vez la percibe como una amenaza a su dominio evidenciaría la falsedad de la hipótesis de Bernstein sobre la implantación del socialismo a través de la ampliación de las formas democráticas.

Si de los motivos expuestos se deduce para Luxemburg la exigencia de que, contra la desviación reformista, la socialdemocracia se mantenga firme en su original objetivo revolucionario, su posición no comporta, sin embargo, un rechazo de las reformas sociales o de la propia democracia, cuyo destino -como se estudiará más adelante- verá más bien depender de la concepción revolucionaria del movimiento socialista ${ }^{22}$. Por el contrario, reforma y revolución aparecen en su obra como dos momentos diferentes pero complementarios e igualmente imprescindibles de la lucha proletaria. Así, Luxemburg resalta su coincidencia con los revisionistas en la búsqueda de medidas de reforma para la mejora de las condiciones económicas de los trabajadores. Pero frente a la presunción de que las luchas sindicales y políticas propiciarán la fundación de un nuevo orden socialista, su negación de esta dimensión objetiva de la política reformista pretende poner de relieve la dimensión subjetiva que encierra: la importancia de las luchas cotidianas de la socialdemo-

21. Cf. ibid., p. 425.

22. Cf. ibid., p. 426. cracia residiría en su valor educativo y preparatorio del proletariado para la futura construcción del socialismo. Desde la perspectiva de Luxemburg, la limitación y constante revocabilidad de los logros de las luchas sindicales y políticas habrán de llevar al proletariado a cobrar conciencia de la imposibilidad de que estas vías de actuación cambien en lo sustancial su situación, así como de que su superación pasa por una revolución social que suprima los pilares del modelo productivo capitalista ${ }^{23}$. La orientación revolucionaria que en sus inicios caracterizara a la socialdemocracia debe por ello dirigir y encauzar cualquier otro modo de lucha destinado a alterar aspectos parciales de la sociedad capitalista: sin esta meta que a la vez opera como premisa de la acción política, la realización del socialismo queda de antemano excluida y la práctica socialdemócrata se reduce a la relativa contención de los abusos del capitalismo, siempre sujeta a los retrocesos que provocan las fluctuaciones de su dinámica interna y condenada a la esterilidad en el largo plazo.

En esta línea, el texto ¿Reforma social o revolución? recuerda que, en el tránsito de la sociedad feudal a la capitalista, las reformas legales impulsadas por la burguesía no consiguieron suplir a la acción revolucionaria. Más bien, su introducción desembocó en un fortalecimiento de la nueva clase ascendente que desencadenó finalmente su toma del poder político, seguida de la institución de un nuevo sistema jurídico ajustado a sus necesidades e intereses. Pues, como Luxemburg anota, «todo ordenamiento jurídico no es más que un producto de la revolución», ya que «mientras la revolución es el acto político creador de la historia de clases, la legislación expresa la pervivencia política de la

23. Cf. ibid., p. 401 y ss. 
sociedad ${ }^{24}$. Toda reforma legal efectuada sobre la estructura jurídico-política que resulta de la revolución precedente queda así acotada al marco fijado por dicha estructura y se descubre impotente para generar un nuevo orden social. Por tanto, la construcción del socialismo precisaría de un movimiento revolucionario liderado por la clase trabajadora que alumbrara un ordenamiento jurídico capaz de erradicar su explotación en la economía capitalista. No obstante, este planteamiento parece de entrada incompatible con la persistente defensa de la democracia que jalona la trayectoria de Luxemburg, y que culmina con su contundente crítica al desarrollo de la Revolución Rusa por causa de su cancelación: dado su reconocimiento en la democracia de un producto netamente burgués y, en consecuencia, inscrito en la organización jurídica de la sociedad capitalista, su reivindicación de la misma semejaría entrar en confrontación con su visión de la revolución proletaria al modo de un acto político creador al servicio del surgimiento de un sistema jurídico coherente con los postulados del socialismo. Con el fin de aclarar si en la posición de Rosa Luxemburg se da o no tal incongruencia, en el siguiente punto se indagará sobre el singular lugar que concede a la democracia en el proyecto revolucionario.

\section{Democracia y revolución}

Como se muestra en el anterior apartado, uno de los aspectos que para Luxemburg harían patente el carácter contradictorio del sistema de producción capitalista radica en la relación que su clase dominante mantiene con la forma jurídica de la democracia. En concreto, esta contradicción, ya subrayada por Marx, estriba

24. Ibid., p. 428. en que si bien la democracia moderna irrumpe como una demanda de la burguesía para el libre ejercicio de su poder de clase, su preservación de tal poder exige simultáneamente que la propia burguesía coarte el cumplimiento efectivo o la realización material del ideal democrático que invoca. 0 , por decirlo en otros términos: el poder de clase de la burguesía no consiente, paradójicamente, que la forma jurídica que ella misma impone se realice de manera plena. Semejante contradicción se asienta sobre una cuestión previamente abordada, a saber, que bajo el ordenamiento jurídico de la sociedad capitalista las relaciones de intercambio se piensan como relaciones entre individuos iguales que estipulan libremente sus contratos de intercambio. Ahora se ha de añadir a ello que esta concepción representa para Marx un requisito esencial de la estructura económica de la sociedad capitalista: teniendo en cuenta que su rasgo fundamental se cifra en que la totalidad de las cosas se constituyen o aparecen en ella como mercancías -es decir, cosas producidas de antemano para su intercambio ${ }^{25}$-, los individuos que componen tal sociedad deben comparecer en el contexto de dicha estructura como sujetos que se definen a través de sus relaciones de intercambio. A ello subyace una abstracción de sus diferencias particulares por la que todos los individuos, en calidad de simples poseedores de mercancías canjeables por otras mercancías de igual valor de cambio, se determinan tanto en virtud de su igualdad formal como por la libertad o ausencia de coer-

25. Para esta tesis, cf. Martínez Matías, P., "Producto y mercancía: sobre la constitución ontológica de la modernidad a partir de Heidegger y Marx", Lógos. Anales del Seminario de Metafisi$c a$, Vol. 47 (2014), p. 212 y ss. 
ción que se presupone en la validez de los contratos de intercambio ${ }^{26}$.

Pero Marx señala asimismo que la exigencia de igualdad y libertad de todos los individuos que comporta la propia estructura económica de la sociedad capitalista no se presenta bajo ese rostro en el seno de esta misma sociedad. Ante la sociedad burguesa tales caracteres se manifiestan -manifestación que implica asimismo una cierta forma de encubrimiento- bajo la forma ideológica o expresión ideal que consiste en la afirmación teórica de una naturaleza igual y libre intrínseca al ser humano en función de la cual se reclama una organización jurídica acorde a ella. Las ideas de libertad e igualdad que afloran en la sociedad burguesa, y que ésta entiende como propiedades objetivas y naturales del ser humano, no serían entonces más que un mero reflejo ideológico de las condiciones materiales que posibilitan el funcionamiento de la producción capitalista $^{27}$. No otra cosa que tales condiciones, pertenecientes a la base económica, justifica la emergencia de la noción de derecho como derecho igual de la que deriva la forma de Estado de la república democrática. Pues en la medida en que el concepto de derecho igual se concreta en la instauración de un sistema de garantías que, mediante fórmulas legales, debe asegurar los mismos derechos y deberes a todos los miembros de la sociedad, la autoridad responsable de hacer cumplir la ley, encarnada en la figura del Estado, ha de emanar forzosamente del todo social. Para ello deviene imprescindible la implantación del sufragio universal como único mecanismo legítimo de decisión

26. Cf. Marx, K., Grundrisse der Kritik der Politischen Ökonomie (Rohentwurf) 1857-1858, op. cit., p. 152 y ss.

27. Cf. ibid., p. 156. sobre aquellos aspectos que afectan a la totalidad de integrantes de la sociedad. E igualmente imprescindible resulta el que se garantice el conjunto de libertades -de voto, reunión y comunicación- del que precisa la existencia del sufragio universal como prerrogativa definitoria de la idea de república democrática ${ }^{28}$.

Sin embargo, las investigaciones de Marx sobre los procesos de valorización del valor que rigen en la producción capitalista revelan a su vez cómo su estructura económica impide la realización efectiva de las ideas de igualdad y libertad que sustentan la noción de un derecho igual para la totalidad de sus individuos. Por un lado, para el enfoque marxiano la relación de intercambio que envuelve la compra-venta de la fuerza de trabajo no supone un intercambio de mercancías de igual valor, ya que no cabe obtención de plusvalía más que en el caso de que el trabajador no reciba en concepto de salario el equivalente del valor que rinde su fuerza de trabajo. Por otro, en la sociedad capitalista el ejercicio de la libertad sólo queda materialmente asegurado para los poseedores de mercancías, mientras que quienes carecen de toda otra mercancía al margen de su fuerza de trabajo, lejos de actuar libremente, se ven forzados a venderla según los criterios estipulados por sus compradores. Es por esta razón por la que las ideas de libertad e igualdad que vertebran la organización política de la sociedad capitalista se perfilan como formas ideológicas que contienen un claro componente de falsedad: la reivindicación de tales ideas oculta la imposibilidad de su cumplimiento en un régimen de producción que se articula estructuralmente sobre la desigualdad y la

28. Cf. Martínez Marzoa, F., La filosofía de "El capital" de Marx, Taurus, Madrid, 1983, pp. 141-144. 
falta de libertad de la mayor parte de sus miembros ${ }^{29}$. Esta dimensión ideológica se da a ver en el hecho de que el reconocimiento jurídico de un conjunto de derechos y libertades a todos los individuos que involucra la configuración democrática de la sociedad burguesa se reduce en ella a un ideal separado de la reflexión sobre las condiciones materiales que permitirían su ejercicio efectivo, del que el proletariado queda ineludiblemente excluido como clase desposeída de mercancías. Pero ese mismo cariz ideológico también explica que las constituciones en apariencia democráticas de las sociedades capitalistas incurran invariablemente en lo que se ha calificado de "fraude democrático": mediante recursos variados, que incluyen la apelación al "estado de excepción" o la utilización de formulaciones ambiguas, ni tan siquiera garantizan, en la mera formalidad de los enunciados que las componen, el reconocimiento pleno -y esto significa: en todos los casos y bajo cualquier circunstancia- de los derechos y libertades que proclaman ${ }^{30}$. Ambos factores atestiguarían la actitud defensiva de la burguesía ante la forma política que ella misma demanda en su ascenso histórico, fruto de la ambivalencia que su afán de conservar su posición de dominio le obliga a adoptar frente a ella.

Sobre la base de estos análisis, Rosa Luxemburg considera que el único camino para la realización efectiva de la democracia, inevitable y sistemáticamente

29. Cf. Marx, K., Das Kapital. Kritik der politischen Ökonomie. Buch I: Der produktionsprozeß des Kapitals, en Karl Marx - Friedrich Engels. Werke, Band 23, hrsg. vom Institut für Marxismus-Leninismus beim ZK der SED, Dietz, Berlín, 1972, pp. 189-91.

30. Cf. Martínez Marzoa, F., De la revolución, Alberto Corazón, Madrid, 1976, p. 69. obstaculizada por la burguesía que le dio origen, reside en la conquista proletaria del poder político. Y contra la tesis de que su hipotética extensión por medio de reformas legales la haría superflua, anuncia que la democracia regentada de facto por la burguesía «convierte esa conquista del poder tanto en una necesidad como en una posibilidad» ${ }^{31}$. En paralelo con lo dicho sobre la voluntad de auspiciar reformas sociales, Luxemburg se refiere en este caso a que la lucha de la socialdemocracia por la ampliación de los derechos democráticos descubre al proletariado la inviabilidad de la realización del ideal democrático burgués en la sociedad capitalista. Con ello, su toma del poder pasa a percibirse como una necesidad precisamente porque sólo la ocupación del proletariado del poder político podría abocar al cumplimiento efectivo del concepto de democracia. Pero esto implica que, en la reflexión teórica de Luxemburg, el orden jurídico a promulgar por la revolución proletaria no se aleja en modo alguno de las formas democráticas burguesas: antes bien, se trataría de un sistema legal que, adoptando la forma jurídica de la democracia heredada de la burguesía, al mismo tiempo aspira a salvar las contradicciones inmanentes a su aplicación en el marco de la sociedad capitalista a través de la producción y mantenimiento de aquellas condiciones materiales que asegurarían la transformación del ideal democrático en una realidad consumada para todos los miembros de la sociedad ${ }^{32}$. En este

31. Luxemburg, R., "Socialreform oder Revolution?", op. cit., p. 432.

32. De idéntica forma, ya Marx había planteado, en su "Crítica al Programa de Gotha", que en la construcción del orden socialista, como sociedad que "acaba de salir de la sociedad capitalista", «el derecho igual sigue siendo, según el principio, el derecho burgués, aun cuando ahora el principio y 
sentido, esa república democrática que pretende superar el hiato entre el simple ideal y los requisitos económicos indispensables para su materialización efectiva se erige para Luxemburg en la forma jurídica a instituir por el proletariado en el poder en tanto forma jurídica que habría de adquirir aquello que Marx designara como la "dictadura del proletariado" 33 .

Esta cuestión cobra neta visibilidad en el texto que Rosa Luxemburg, entre 1917 y 1918, dedica al examen de los primeros movimientos del partido bolchevique tras su toma del poder. Allí destaca que la distinción crítica entre la forma política de la democracia, que bajo el dominio burgués se traduce en la proclamación de la igualdad y la libertad en un plano puramente formal, y su contenido, término que apunta a la desigualdad y falta de libertad de la mayoría reinantes en la sociedad capitalista, no conlleva en modo alguno el repudio de tales libertad e igualdad formales en el proyecto revolucionario. Por el contrario, en esta distinción se ubica el motor que debe orientar al proletariado hacia la conquista del poder político, no con el fin de anular la democracia, sino para luchar por que la eliminación del modo de producción capitalista habilite el tránsito desde la mera formalidad a la realización del ideal burgués en el todo social ${ }^{34}$. Por

la práctica ya no se tiran de los pelos». Cf. Marx, K., "Kritik des Gothaer Programms", en Karl Marx - Friedrich Engels. Werke, Band 19, hrsg. vom Institut für Marxismus-Leninismus beim ZK der SED, Dietz, Berlín, 1987, p. 20.

33. Luxemburg, R., "Socialreform oder Revolution?", op. cit., p. 433. Para la coincidencia entre la dictadura del proletariado y la república democrática, cf. igualmente, entre otros lugares, Marx, K., "Kritik des Gothaer Programms", $o p$. cit., pp. 28-29.

34. Cf. Luxemburg, R., "Zur russichen Revolution", en Gesammelte Werke. Band IV, Dietz, otra parte, aun cuando este escrito intenta plantear una defensa de la revolución bolchevique, sus observaciones sobre las decisiones de Lenin en lo que respecta a la política agraria, la cuestión de las nacionalidades y, fundamentalmente, la utilización de los principios democráticos, no eluden la crítica allí donde aquellas se desvían de la interpretación de Luxemburg de la filosofía marxiana ${ }^{35}$.

Ya en el punto en el que desaprueba la reivindicación bolchevique del derecho de autogobierno de las distintas nacionalidades del antiguo Imperio Ruso, Luxemburg argumenta que el verdadero "derecho a la autodeterminación" en Rusia anida en «el aparato de las libertades democráticas fundamentales de las masas populares» ${ }^{36}$, en su opinión fríamente despreciadas por el partido de Lenin.

Berlin, 1974, p. 363. A este respecto ha señalado acertadamente Atilio A. Borón: «Le cupo a Rosa Luxemburgo el honor de haber sido quien, con singular agudeza, reconoció que aquellas libertades, derechos y garantías individuales apostrofadas por su supuesta condición de "burguesas" seguian siendo condiciones necesarias $-\mathrm{si}$ bien no suficientes- para la construcción de una democracia socialista. Su opción revolucionaria no la hizo sucumbir ante la tentación -que tantos estragos hiciera en la izquierda- de denostar a la democracia burguesa por ser exclusivamente "formal"» (Sader, M., Gentili, P. (comp.), La trama del neoliberalismo. Mercado, crisis y exclusión social, Eudeba, Buenos Aires, 1999, p. 55).

35. Cabe decir por ello que el tono fundamental de este texto expresa una suerte de "solidaridad crítica" con la Revolución Rusa, cuyos actores políticos serán vistos en todo caso como camaradas de un proyecto común, más allá de las insuficiencias o errores que Luxemburg señale en su actuación. A este respecto, cf. Fiorillo, M., "The freedom to think differently. Rosa Luxemburg's democratic critique of Leninism", Lo Sguardo. Rivista de Filosofia, $\mathrm{n}^{\circ}$ 25, 2017 (III), pp. 97-107. 36. Ibid., pp. 346-347. 
Pues a pesar de que los bolcheviques habían exigido la convocatoria de una Asamblea Constituyente antes de su llegada al poder, su disolución en enero de $1918^{37}$ marcaría decisivamente el rumbo de la revolución rusa. Luxemburg admite que la Asamblea Constituyente en vigor en ese momento, electa antes de la Revolución de Octubre, no podía sino representar intereses distintos a los del proyecto socialista. Pero denuncia como un error histórico el que, en lugar de anular esa Asamblea Constituyente ya superada por los acontecimientos y convocar sin demora a elecciones para una nueva Asamblea, el partido bolchevique suspendiera toda institución democrática, declarando su inutilidad e inoperancia durante la revolución. Contra esta postura Luxemburg aduce que en «la vida política activa, sin trabas, enérgica, de las más amplias masas populares» ${ }^{38}$ se hallaría el más eficaz correctivo a las limitaciones e inconvenientes de los que, en efecto, adolecen tales instituciones. Y juzga la eliminación bolchevique del aparato democrático como un remedio peor que la enfermedad que, presumiblemente, habría de entrañar el "mecanismo farragoso" de aquellas para el ritmo imprevisible y en ocasiones acelerado del proceso revolucionario.

Profundizando en esta idea, el texto sobre la Revolución Rusa censura las restricciones impuestas por el gobierno bolchevique al derecho al sufragio, así como el establecimiento de los soviets como ex-

37. En este texto que dedica a la Revolución Rusa, Luxemburg sitúa erróneamente la disolución de la Asamblea Constituyente en noviembre de 1917, probablemente a causa de la dificultad de obtener información fiable sobre su desarrollo desde su encierro en la prisión de Breslau, donde permanecería hasta noviembre de 1918.

38. Ibid., p. 356. clusivo órgano de decisión popular, para reclamar la implantación del sufragio universal y la restauración de los derechos democráticos que posibilitan la existencia de una vida pública y de una actividad política generalizada más allá de los mecanismos de representación: absoluta libertad de prensa y derecho ilimitado de asociación y reunión. Si en tales derechos emplaza los precisos instrumentos para que la masa del pueblo alcance experiencia política y participe activamente en las cuestiones que incumben al todo social, su condena a toda forma de restricción de las libertades políticas evidencia en Luxemburg una rigurosa comprensión de la noción misma de democracia como sistema de garantías que, en su equivalencia con un régimen de derechos y libertades, sería contradictorio de no poseer éstos un carácter estrictamente universal, es decir, de no regir una igualdad de derechos y libertades para todos y cada uno de los individuos. De ahí que afirme taxativamente, en una bien conocida sentencia: «La libertad sólo para los que apoyan al gobierno, sólo para los miembros de un partido (...), no es libertad en absoluto. La libertad es siempre y exclusivamente para el que piensa de manera diferente» ${ }^{39}$. De acuerdo con esta consigna, su escrito insiste en que la Revolución Rusa recién acaecida no habrá de conducir a la realización del proyecto socialista si no procede a la instauración y preservación de una libertad política ilimitada. 0 , lo que es lo mismo: en el caso de que tal proyecto no coincida con el efectivo cumplimiento del ideal democrático, que no tolera la negación de las libertades políticas a determinados sectores de la población sin que ello involucre la aplicación de un concepto de democracia en sí mismo inconsistente

39. Ibid., p. 359. 
por falsear la universalidad inherente a la propia noción de derecho ${ }^{40}$.

Por ello, el análisis sobre la Revolución Rusa finaliza con un rechazo a la disyuntiva excluyente entre dictadura y democracia en la que, avalados por diferentes razones, confluyen tanto los dirigentes del partido bolchevique como el líder socialdemócrata Kautsky. Si éste se decanta a favor de la democracia contraponiéndola a la revolución socialista, el que Lenin y Trotsky se sitúen del lado de la dictadura, desdeñando la democracia como un producto de la burguesía, indica para Luxemburg su opción por la dictadura de un puñado de personas, esto es, una dictadura a su juicio entendida según el modelo burgués y que se apartaría tanto como la idea de democracia apoyada por Kautsky de lo que estima una genuina política socialista. A tenor de esta crítica, el texto concluye con una inequívoca identificación entre la dictadura del proletariado y la "democracia sin límites"41 en función de la cual se condena el uso del terror por parte del nuevo gobierno ruso: aun concediendo que los errores de la política bolchevique obedecerían a las difíciles circunstancias en que se acometió la empresa revolucionaria y al escollo que éstas habrían supuesto para la coherente aplicación de los principios democráticos, semejantes prácticas quebrarían de manera radical el compromiso democrático

40. Sirva de ejemplo el que, desde el momento en que se priva a determinados colectivos del derecho de comunicación y reunión, se impide que aquellos que sí gozan de tales derechos puedan comunicarse o reunirse con el sector que carece de ellos, lo cual implica automáticamente la restricción de la libertad de todos. Cf. Martínez Marzoa, F., Revolución e ideología, Fontamara, Barcelona, 1979, p. 79.

41. Luxemburg, R., "Zur russichen Revolution", op. cit., p. 363 . que en su perspectiva resulta indisociable del proyecto revolucionario.

Pero en esa categórica vindicación de las formas democráticas no sólo se expresa un pronunciamiento teórico sobre su inexcusable vinculación con el objetivo revolucionario, sino también la percepción del escaso calado del ideal democrático entre la población alemana. En el ensayo de 1916 La crisis de la socialdemocracia, en el que se entrega a una implacable crítica al Partido Socialista Alemán por su traición a la clase trabajadora al aprobar la intervención de Alemania en la Primera Guerra Mundial, Luxemburg se lamenta amargamente de la suspensión de las libertades de prensa y reunión durante la dictadura militar de facto vigente en ese momento a causa de la contienda, al tiempo que acusa a la socialdemocracia de sostener tácitamente ese estado de sitio y confiar con pueril ingenuidad en que el fin de la guerra traería consigo una ampliación de las libertades democráticas de la clase obrera como recompensa a su lucha por la patria. La aceptación sin resistencia de este escenario pondría de manifiesto para Luxemburg la carencia de un suelo apropiado en la sociedad alemana para el sólido arraigo de las libertades políticas: así, en este texto recuerda que los escasos derechos políticos reconocidos en Alemania antes del inicio de la guerra no se conquistaron gracias a luchas políticas revolucionarias -tal y como habría sucedido en Francia o en Inglaterra-, sino que fueron el fruto coyuntural de la política de Bismarck. Y la constatación de la ausencia de una tradición democrática en la historia del pueblo alemán le Ileva a hacer notar que «los peligros para el "desarrollo liberador de Alemania" no radican, como opina la fracción del Reich, 
en Rusia, sino en la misma Alemania »2 . Con ello, Luxemburg demuestra haber vislumbrado, con notable clarividencia, el germen que años más tarde habría de cristalizar en el amplio respaldo del pueblo alemán al régimen nacionalsocialista.

El tono pesimista de este texto, que no deja de señalar como un obstáculo al avance del socialismo las muertes masivas del proletariado ya instruido en sus principios, y en el que se apela a su voluntad bélica en términos de un suicidio de la clase obrera europea, da cuenta de la profunda decepción de Luxemburg con la socialdemocracia alemana a consecuencia del abandono de lo que en sus comienzos tal vez fuera su principal finalidad ${ }^{43}$ : esclarecer al proletariado sobre su situación e inculcar en él la conciencia revolucionaria, tarea en la que la democracia desempeñaría también una función crucial. Pues por más que las contradicciones de la sociedad capitalista condenen a la impotencia toda lucha parlamentaria por la extensión de los derechos democráticos de la clase obrera, la participación en las instituciones democráticas debería haber servido de plataforma al Partido Socialdemócrata para impulsar al proletariado a trascender el orden burgués y abrir así la posibilidad de su toma del poder político. En este orden de cosas, Luxemburg resalta el espacio de influencia que su presencia en el parlamento habría brindado a la socialdemocracia, desperdi-

42. Luxemburg, R., "Die Krise der Sozialdemokratie", en Gesammelte Werke. Band. IV, op. cit., p. 128.

43. Para un análisis más pormenorizado de la crítica que Luxemburg realiza en este texto a la política efectiva de la socialdemocracia a partir de su inesperado y contradictorio apoyo a la participación de Alemania en la Primera Guerra Mundial, cf. Haug, F., Rosa Luxemburg y el arte de la política, Tierra de nadie, Madrid, 2013, p. 114 y ss. ciado durante los años de la Primera Guerra Mundial tras su imprevisto apoyo a la misma, para apuntar que «precisamente las tribunas parlamentarias, los únicos puestos libres, de gran audiencia y visibilidad internacional, podrían convertirse en poderosos instrumentos de movilización popular si fueran utilizadas por la representación socialdemócrata para formular tajante y claramente los intereses, las tareas y las reivindicaciones de la clase obrera» ${ }^{44}$. Sobre esta cuestión, que gravita básicamente en torno a la relación entre el partido revolucionario y la clase obrera, se focalizará el último punto de este ensayo.

\section{Conciencia revolucionaria versus populismo}

Los trabajos sobre la obra de Rosa Luxemburg le han atribuido con frecuencia, en lo que concierne a la problemática de la puesta en marcha y desarrollo de los procesos revolucionarios, una posición que se ha dado en llamar "espontaneismo" y que la acercaría antes a la teoría anarquista de Proudhon o Bakunin que a lo expuesto sobre esta cuestión desde las filas de la socialdemocracia. Pese a no existir unanimidad sobre el significado conferido a este concepto, quienes lo aplican convergen en asignar a Luxemburg la tesis de que la revolución derivaría básicamente de la espontaneidad de las masas proletarias: de manera autónoma y antes de la intervención de cualquier instancia diferenciada de ellas, su conciencia política despertaría a través de la propia acción revolucionaria, empren-

44. Luxemburg, R., "Die Krise der Sozialdemokratie", op. cit., p. 150. Sobre el papel que Luxemburg concede a la lucha parlamentaria, cf. Haug, F., Rosa Luxemburg y el arte de la política, op. cit., p. 170 y ss. 
dida al modo de una reacción inmediata ante la precariedad de sus condiciones de vida. De acuerdo con esta interpretación, lo designado por la palabra "conciencia", aquí entendida en el doble sentido de la conciencia de sí de la clase trabajadora y del elemento consciente que representa el partido político, nacería entonces del carácter espontáneo y no mediado de la lucha revolucionaria iniciada por la primera ${ }^{45}$. Pero aun cuando los textos de Luxemburg no abordan sistemáticamente esta cuestión y la dispersión de sus consideraciones sobre la misma tiende a inducir a confusión, la atenta lectura de sus principales escritos inclina más bien a desmentir esta explicación del papel que la espontaneidad de las masas juega en su obra.

De entrada, la idea de que Luxemburg habría defendido que la acción revolucionaria espontánea antecede a la aparición de la conciencia de su necesidad, es decir, de lo que cabría designar como la "conciencia revolucionaria", al tiempo que constituye el sustrato de su surgimiento, no parece coherente con la afirmación que cierra el prólogo de ¿Reforma social o revolución?, en el que escribe: «Todo el poder del movimiento obrero moderno descansa sobre el conocimiento teórico» ${ }^{46}$. Este conocimiento teórico al que Luxemburg apela remite a los análisis de Marx sobre la estructura económica de la sociedad capitalista en confrontación crítica con la economía política. Lo cual equivale a decir: a su estudio de la ley del valor y de los mecanismos de valorización que presiden este modo productivo, cuyo examen revela igualmente la naturaleza potencialmente emancipatoria que los pro-

45. Cf. Basso, L., El pensamiento político de Rosa Luxemburg, op. cit., p. 146.

46. Luxemburg, R., "Socialreform oder Revolution?", op. cit. p. 371. cesos de racionalización de la producción -siempre incompletos y contradictorios bajo la dirección de la burguesía-, a través de su creciente recurso a la ciencia y la técnica, tendrían para el proletariado y, por ende, para la sociedad en su conjunto. Enfatizando la esencialidad del conocimiento de la obra de Marx para la eventual emancipación de la clase obrera, Luxemburg plantea en 1903: «El tránsito histórico intuido por Marx no puede ser en modo alguno realizado sin que el conocimiento marxiano llegue a ser el conocimiento de una determinada clase social, el proletariado moderno ${ }^{47}$. La respuesta a la pregunta acerca de los motivos por los que la clase obrera precisa de ese conocimiento sobre el funcionamiento del capitalismo se localiza en la propia convicción marxiana de que la desaparición del trabajo asalariado depende de un desmantelamiento o desmontaje del modo de producción capitalista sólo viable a partir de la voluntad y la acción consciente del proletariado. Pues así como la burguesía se encuentra en virtud de la propia dinámica material del capitalismo, esto es, de manera espontánea y no necesariamente consciente, en una posición de dominio frente a las demás clases sociales, la superación del dominio burgués exige del proletariado una comprensión de la ley económica de este régimen productivo que no corresponde al orden de lo espontáneo o inmediato, sino al de la reflexión o el juicio teórico sobre lo dado: si tal comprensión por parte del proletariado se traduce en el descubrimiento del carácter estructural de la explotación que sufre, inalterable en un modo de producción sustentado sobre la extracción de plusvalía, en ella radica la condición de posibilidad de la irrupción de un proyecto

47. Luxemburg, R., "Karl Marx", en Gesammelte Werke. Band I/2, Dietz, Berlin, 1979, p. 377. 
consciente y expresamente asumido que, con el objetivo de abolir la explotación de manera definitiva, tenga por horizonte la desarticulación del régimen capitalista ${ }^{48}$. Tal proyecto consciente no sería otra cosa que aquello que Marx piensa bajo el término "revolución", y marcaría la diferencia entre cualquier forma de resistencia de la clase trabajadora ante la opresión burguesa y la acción propiamente revolucionaria, caracterizada frente a la primera por formar parte de ese proyecto consciente vertebrado por la aprehensión de la legalidad interna que gobierna la maquinaria capitalista. Por lo demás, esto significa que, en contraposición a la "falsa" conciencia burguesa, procedente de una imagen de este régimen productivo forjada desde la óptica del capitalista individual y cuyo reflejo más palpable se hallaría en el carácter apologético de la economía política, el proletariado necesita de una conciencia cuya verdad anida en la adopción del punto de vista de la totalidad, es decir, en una visión de conjunto de este sistema productivo que le procure el discernimiento de la estructura económica subyacente a la diversidad de sus fenómenos ${ }^{49}$.

48. Cf. Marx, K., "Lohn, Preis und Profit", en Karl Marx - Friedrich Engels. Werke, Band 16, hrsg. vom Institut für Marxismus-Leninismus beim ZK der SED, Dietz, Berlín, 1962, p. 152. Cf. asimismo Lukács, G., Historia y conciencia de clase, Grijalbo, Barcelona, 1975, especialmente p. 138 y ss.

49. Cf. Lukács, G., Historia y conciencia de clase, op. cit., pp. 130 y 136. Una exposición más exhaustiva del sentido e implicaciones que esta premisa marxiana cobra en el pensamiento de Rosa Luxemburg, analizados por G. Lukácks en su ensayo "Rosa Luxemburgo como marxista", se encuentra en Herrera Flores, J., "De la rueda y el freno. El camino hacia la democracia en Georg Lukács y Rosa Luxemburg”, en J. Trías y M. Monereo (eds.), Rosa Luxemburg. Actualidad y clasicismo, op. cit., p. 112 y ss. Sobre esta
Obviamente, sería utópico esperar que el proletariado alcanzara por sí mismo una adecuada comprensión de la ley del valor que rige en el modo de producción capitalista, dilucidada principalmente por Marx en una obra de la complejidad de El capital. Por esta razón, la transmisión del conocimiento que permita al proletariado entender su situación de forzosa explotación en el marco del capitalismo y resolverse en función de él por la acción revolucionaria en tanto acción conscientemente encaminada a su desintegración, representaría según Luxemburg una de las tareas fundamentales del partido revolucionario como instancia penetrada por tal conocimiento y capaz de ponerlo a disposición de la clase obrera. Así lo evidencia el que el socialismo constituya a su juicio el primer movimiento de la historia guiado por la meta de «inyectar en la acción social de los hombres un sentido consciente, un pensamiento planificado $y$, por consiguiente, la libre voluntad», a fin de que el proletariado, "dotado de clara conciencia sobre sus objetivos», se convierta en el conductor de la historia ${ }^{50}$. O que, en un sentido análogo, proclame que el trabajo de la socialdemocracia debe consistir en "esclarecer, hacer conscientes a las masas trabajadoras de sus intereses de clase y de sus tareas históricas ${ }^{51}$ para que éstas, a partir de su comprensión de las contradicciones del régimen de producción capitalista, pugnen por la realización del socialismo. In-

cuestión, cf. igualmente Löwy, M., El marxismo olvidado, Fontamara, Barcelona, 1978, p. 59 у ss., en especial p. 64.

50. Luxemburg, R., "Die Krise der Sozialdemokratie", op. cit., pp. 61-62.

51. Luxemburg, R., "Verteidigungsrede vor der Frankfurter Strafkammer", en Gesammelte Werke. Band III, Dietz, Berlin, 1974, p. 396. 
cluso el texto de 1906 Huelga de masas, partido y sindicato, tomado a menudo por los intérpretes de Luxemburg como el escrito en el que con mayor nitidez se expresaría su concepción espontaneista de los movimientos revolucionarios, destaca que, en el caso de iniciarse en Alemania un período revolucionario, los movimientos de masas actuarían con tanto mayor empuje «cuanto más poderosa haya sido la tarea educadora llevada a cabo hasta ese momento por la socialdemocracia» ${ }^{52}$. Y también allí anota que es de esta organización política de donde fluye «la claridad política, la fuerza y la unidad del movimiento obrero» ${ }^{53}$, observación que pondría de relieve el carácter crucial que confiere al partido en la adquisición por parte del proletariado de aquella forma de conciencia que opera como desencadenante de la acción revolucionaria.

Pero que Luxemburg propugne que la conciencia revolucionaria emerge en el proletariado por obra de la actividad formativa y esclarecedora del elemento consciente que encarna el partido revolucionario no implica que ubique en éste el origen de la lucha de clases. Antes bien, la lucha de clases se encuadraría como tal en el plano de la espontánea combatividad y resistencia de las clases trabajadoras ante la intuición de la desigualdad reinante en la sociedad capitalista, que las sentencia a condiciones de precariedad, sufrimiento e inseguridad en contraste con la riqueza de los sectores más favorecidos. Pese a la tendencia del capitalismo a anular tal combatividad, convirtiendo a los individuos de la clase

52. Luxemburg, R., "Massenstreik, Partei und Gewerkschaften", en Gesammelte Werke. Band II, Dietz, Berlin, 1974, p. 145.

53. Ibid., p. 143. obrera en "máquinas muertas"54 proclives a la obediencia y la resignación, en aquellos momentos históricos en los que cobra protagonismo esa lucha espontánea configura el espacio que habría dado lugar a la fundación del Partido Socialdemócrata, al que Luxemburg, subrayando su enraizamiento en las luchas que se producen en el contexto de la sociedad capitalista sin mediación de instancias políticas, concibe como el "núcleo organizado de la clase obrera" o la "vanguardia de la totalidad del pueblo trabajador"55. Sin embargo, tales luchas de carácter espontáneo no coinciden sin más con la existencia de un proyecto revolucionario: como se ha comentado, no hay proyecto consciente ni, en consecuencia, acción revolucionaria sin una clarividencia o discernimiento de la ley del valor enunciada por Marx que desemboque en la pretensión de desmontar el sistema de producción capitalista; y tal clarividencia pertenece en primer término a la organización política del partido, cuya misión estriba en introducir la conciencia revolucionaria en la lucha de clases con el propósito de dar a ver al proletariado los fines que deben guiar su acción. Por tanto, es errónea la discrepancia que, sobre esta concreta cuestión, suele apreciarse entre la posición de Luxemburg y la de Lenin tal y como éste la formulara en su escrito ¿Qué hacer?: para ambos, la conciencia revolucionaria llegaría al proletariado "desde fuera", siempre y cuando este "afuera" se refiera al partido revolucionario ${ }^{56}$.

54. Cf. Luxemburg, R., "Was will der Spartakusbund?", en Gesammelte Werke. Band IV, op. cit., p. 445 .

55. Cf. Luxemburg, R., "Massenstreik, Partei und Gewerkschaften", op. cit., p. 143.

56. Cf. Lenin, V. I., “¿Qué hacer? Problemas candentes de nuestro movimiento", en Obras completas, Tomo V, Akal, Madrid, 1976, p. 381 y ss. 
No obstante, Luxemburg se enfrentaría al enfoque dirigista de Lenin ${ }^{57}$ para insistir, en línea con su radical defensa de las formas democráticas, tanto en la insustituible función de los movimientos de masas en el surgimiento y despliegue de los procesos revolucionarios como en el valor educativo inmanente a tales procesos, que ampliarían la conciencia política del proletariado y lo prepararían para el ejercicio del poder. Por un lado, la espontaneidad de la clase obrera que Luxemburg, en efecto, reivindica en la puesta en marcha de los procesos revolucionarios tan sólo apela a que su inicio no consiente ser sometido a alguna suerte de calculada planificación ni obedece a los designios u órdenes del partido revolucionario. Por otro, es cierto que Luxemburg escribiría que «las revoluciones no se aprenden en la escuela» ${ }^{58,}$ incidiendo así en la vertiente formativa o instructiva para las masas de la propia acción revolucionaria. Pero ninguno de estos aspectos que integran su polémica con Lenin contradice la idea de que la manifestación de la conciencia revolucionaria en la clase obrera provendría de la acción esclarecedora del partido revolucionario. Si a este respecto puede hacerse valer la distinción entre el conocimiento teórico inculcado por el partido y el aprendizaje práctico ganado en el curso de la lucha política ${ }^{59}$ como momentos idénticamente ineludibles de cara al eventual triunfo de la revolución, para Luxemburg ese aprendizaje práctico del proletariado carecerá de toda significación revolucionaria si no se alza sobre el terreno de una compren-

57. Cf. Luxemburg, R., "Organisationsfragen der russischen Sozialdemokratie", en Gesammelte Werke. Band I/2, op. cit., p. 424 y ss.

58. Luxemburg, R., "Massenstreik, Partei und Gewerkschaften”, op. cit., p. 132.

59. Cf. ibid., pp. 144-145. sión teórica que inscriba su acción combativa en un proyecto conscientemente orientado a la destrucción del régimen capitalista. De lo expuesto se desprende que si bien el proletariado se erige en los textos de Luxemburg en el verdadero actor o sujeto de la revolución, irreemplazable en su actuación por la de cualquier grupo de dirigentes políticos ${ }^{60}$, su espontaneidad en la empresa revolucionaria se revela efecto de una conciencia que, lejos de construirse en respuesta inmediata a sus condiciones materiales, sería el producto de una reflexión primero asimilada por el partido revolucionario y accesible al proletariado gracias a éste ${ }^{61}$.

60. Cf. Geras, N., "La democracia y los fines del marxismo", en J. Trías y M. Monereo (eds.), Rosa Luxemburg. Actualidad y clasicismo, op. cit., p. 145.

61. En este sentido, disentimos de la idea de que en el pensamiento de Rosa Luxemburg se daría «una circularidad entre conciencia y acción» según la cual «la conciencia, la teoría, se crea en la lucha y, a su vez, esa lucha es producida por la conciencia» (Cf. Herrera Flores, J., "De la rueda y el freno. El camino hacia la democracia en Georg Lukács y Rosa Luxemburg”, en J. Trías y M. Monereo (eds.) Rosa Luxemburg. Actualidad y clasicismo, op. cit., p. 115): si por conciencia se entiende conciencia revolucionaria, es decir, asociada a un proyecto de desmantelamiento del régimen de producción capitalista, ésta no puede surgir como tal, según los escritos de Luxemburg, a través de la lucha espontánea de la clase obrera ante las condiciones de vida que dicho régimen le impone. Según se ha argumentado, la conciencia revolucionaria exige una comprensión teórica del funcionamiento del capitalismo que la clase trabajadora difícilmente puede alcanzar por sí misma y de distinta naturaleza al aprendizaje práctico adquirido a través de esa lucha espontánea. Sin duda, semejante aprendizaje práctico contribuiría a reforzar y consolidar la conciencia revolucionaria del proletariado. Pero el nacimiento de ésta no se deja explicar a partir de tal aprendizaje en virtud de su dependencia del conocimiento teórico. 
En lo que atañe a esta problemática, la perspectiva de Rosa Luxemburg arroja luz sobre algunas de las razones por las que la revolución aparece en la actualidad como un sueño lejano de imposible cumplimiento, dada la imposibilidad del cumplimiento de los requisitos que demandaría su potencial acaecimiento. Pues para que la revolución dé comienzo y eche a andar con ciertas probabilidades de éxito no basta con la abertura de un período revolucionario, es decir, un período de agudización de las contradicciones del capitalismo conducente a una crisis económica y política en la que el funcionamiento de este régimen productivo se viera puesto en cuestión. Tampoco sería suficiente que ese período se acompañara de luchas sociales o movimientos de masas, hasta cierto punto esperables como reacción a las circunstancias. Según Luxemburg, para que ambas variables desaten un proceso revolucionario encauzado a la ruptura con el orden social imperante, tales movimientos de masas deberían contar con una claridad de visión sobre la estructura económica del capitalismo impensable sin la presencia de un partido revolucionario dedicado a la lenta labor de suscitarla y promoverla. $Y$ es un hecho que hace ya largo tiempo que tales partidos dejaron de formar parte del abanico de opciones políticas que ofrecen las democracias contemporáneas.

Sin duda, a día de hoy no resulta criticable la actitud de quienes, a la vista de los siniestros escenarios producidos por las revoluciones históricamente acontecidas, crean que nada hay que lamentar ante la actual desaparición de todo partido con aspiraciones revolucionarias. Si a ello se suma la consideración de que las tesis de Luxemburg acerca de las condiciones de emergencia de la revolución probablemente descansen sobre una mirada en exceso exigente e incluso ingenuamente utópica, por disconforme con una presunta naturaleza humana antes inclinada al autoengaño y la ceguera de las pasiones que al discernimiento que brota del sobrio uso de la razón, tal vez deba concluirse igualmente que nada cabe lamentar en su muerte temprana o en el olvido de sus ideas tanto en la socialdemocracia como en los partidos comunistas desgajados de ella. Ahora bien, para que tal conclusión llegara a pronunciarse con justificada convicción, convendría detenerse previamente a valorar qué supuso la pérdida de esa voluntad de esclarecer a las clases trabajadoras sobre los engranajes del capitalismo y sus perennes contradicciones, tan opuesta a toda estrategia populista, que en sus inicios atravesara el programa socialdemócrata y cuyo último baluarte fue Rosa Luxemburg.

Dado que semejante voluntad esclarecedora se hallaba estrictamente ligada al propósito revolucionario, la prevalencia en la socialdemocracia de su desviación reformista hubo de transformarla en una meta por completo prescindible. Asentada sobre las teorías de Bernstein, la socialdemocracia ya no precisaría más que de aquel ascendente que le permitiera recabar un número adecuado de votos para incorporar las pertinentes reformas por medio de la actuación parlamentaria. Para lo cual posee obviamente mayor utilidad la simple propaganda, nunca ajena a la exaltación de los sentimientos, que la costosa transmisión de conocimientos. En el otro ala de la izquierda política, el triunfo de la concepción dirigista de Lenin y la suspensión por parte del partido bolchevique de los aparatos democráticos también tornarían superflua la intención de procurar a la clase obrera la educación política necesaria para garantizar su participación consistente y racional en la vida pública. En este 
sentido, es posible que el carácter radicalmente extemporáneo o intempestivo de los planteamientos de Rosa Luxemburg para la mirada actual no resida tanto en su obstinada defensa de la revolución como vía de acción inexcusable para la conquista efectiva de la justicia social, como en su férreo convencimiento de que la izquierda política debía asumir la tarea de dotar a la población trabajadora del discernimiento económico y la comprensión de la sociedad capitalista que la impulsara a dejar atrás su estructural explotación. De ahí que el vuelco en la izquierda política que comportó la desaparición de la figura de Luxemburg no se cifre únicamente, como señalara Hannah Arendt, en su escisión en dos posiciones en muy escasas ocasiones reconciliadas. También se concreta en el abandono de su original aspiración a proporcionar a la mayoría explotada aquella claridad de visión antes llamada a convertirse en el arma de su potencial liberación.

Si la muerte de Rosa Luxemburg queda ligada a la constitución de la República de Weimar, las causas de su fracaso y del apoyo popular al Partido Nacionalsocialista, punto de partida de uno de los períodos más negros de la historia alemana, siguen siendo objeto de debate y controversia, dada la complejidad de los acontecimientos que se sucedieron desde aquel momento hasta su término ${ }^{62}$. Sin embargo, nadie negará que entre los múltiples factores que desembocaron en la disolución de la República de Weimar ocupa un lugar destacado ese vuelco de doble faz que determinaría el destino de la izquierda política. Más allá de que el enfrentamiento entre socialdemócratas y comunistas jugara en contra de la estabilidad del nuevo orden

62. Cf. Möller, H., La República de Weimar. Una democracia inacabada, Antonio Machado, Madrid, 2012, p. 326 y ss. parlamentario, el desprendimiento tanto de unos como de otros del objetivo de educar políticamente a las masas trabajadoras provocaría el progresivo alejamiento de éstas de ambas fuerzas políticas, contribuyendo al triunfo del nacionalsocialismo. En el caso de la socialdemocracia, porque su posición reformista, indesligable de la renuncia a dicho objetivo, habría de frustrar -tal y como Luxemburg augurara- las expectativas de la población obrera de mejora de sus condiciones de vida: tras refrendarla con su voto, ésta constataría cómo los avances sociales introducidos por el recién estrenado régimen republicano -como la implantación de la jornada de ocho horasse desvanecían en pocos meses ante los imperativos de la maquinaria capitalista63. Por su parte, la facción comunista jamás conseguiría reunir suficientes adhesiones por parte de un proletariado que, cada vez más desasistido del conocimiento teórico, difícilmente disponía de los elementos indispensables para entender el sentido de la acción revolucionaria.

De los errores del Partido Socialdemócrata, así como del temor al contagio de la revolución en curso en Rusia, se nutrirían paulatinamente las fuerzas conservadoras y nacionalistas, que nunca habían confiado en las bondades de la República, para ganar escaños en el parlamento. Pero no fue sino la crisis de 1929, consecuencia de esas contradicciones internas del capitalismo que Bernstein creía en camino de ser superadas, las que empujarían a la población alemana a depositar sus esperanzas de cambio en un partido cuyas tácticas y proceder se han situado entre los

63. Cf. Díez Espinosa, J. R., "La democracia parlamentaria en la República de Weimar: entre el mito y la realidad". Investigaciones históricas. Época moderna y contemporánea, $\mathrm{n}^{\circ}$ 18, 1998, p. 303. 
fenómenos políticos que en la actualidad se vinculan a la noción de populismo ${ }^{64}$. Si es cierto que el populismo representa un fenómeno íntimamente conectado en su aparición con la democracia y, más concretamente, con los problemas que ésta conlleva ${ }^{65}$, la fragilidad de la República de Weimar, agudizada por las repercusiones de una de las crisis más devastadoras que ha conocido el sistema capitalista, encarnaba sin duda un escenario más que favorable para su emergencia. En su interpelación al "pueblo" alemán como sujeto racial, discursivamente construido con elementos antiplutocráticos y nacionalistas, pero también democráticos, a partir de la creación de un antagonismo entre pueblo y Estado, el Partido Nacionalsocialista lograría atraer no sólo a las clases medias, sino también, gracias al empleo de proclamas anticapitalistas, a una clase obrera desmoralizada y desmovilizada ante la impotencia socialdemócrata frente a la crisis y el fracaso de la opción comunista para involucrarla en la acción revolucionaria66.

Que el nazismo se haya juzgado como el estigma de la experiencia democrática europea no ha impedido que la lógica populista, a la que se adscribe esencialmente la apelación a la dimensión afectiva y pasional de los sujetos convocados a articularse en pueblo, haya acabado por impregnar toda forma de hacer política sin distinción de tendencias y al margen de

64. Cf. Laclau, E., Política e ideología en la teoría marxista, Siglo XXI, Madrid, 1986, p. 203.

65. Cf. Delsol, C., Populismos: una defensa de lo indefendible, Ariel, Barcelona, 2015, p. 41 y ss.

66. Cf. Laclau, E., Politica e ideología en la teoría marxista, op. cit., p. 146. Cf. también Möller, H., La República de Weimar. Una democracia inacabada, op. cit., p. 350. diferencias ideológicas ${ }^{67}$. Y aun cuando en estos momentos proliferan en Europa las formaciones populistas de cariz conservador, tampoco la izquierda política ha permanecido ajena a su influencia ni ha eludido en algunos casos la tentación de insertar esa lógica discursiva en sus estrategias para alcanzar el poder, circunstancia quizá previsible desde el momento en que desistiera del proyecto de expandir el conocimiento entre las clases más desfavorecidas. Pero si se tiene en cuenta que la actual hegemonía del ideario neoliberal no constituye más que el reflejo o expresión ideológica de las condiciones socio-económicas que desde finales del siglo XX reclama el funcionamiento del capitalismo ${ }^{68}$, tal vez sea obligado preguntarse, en el caso de que se pretenda propiciar alguna suerte de alternativa a su incuestionable dominio, por la necesidad e incluso la urgencia de rehabilitar aquella antigua aspiración. Pues mientras en la izquierda política no existan indicios de querer hacerse cargo de este interrogante, aquella disyuntiva reivindicada por Rosa Luxemburg que, ante el estado de cosas que nos asiste, parece condenarnos definitivamente a la barbarie, cobra a día de hoy más vigencia que nunca ${ }^{69}$.

67. Cf. Laclau, E., La razón populista, FCE, México, 2004, p. 142 y ss.

68. Cf. Martínez Matías, P., "Del neoliberalismo como ideología”, Lógos. Anales del Seminario de Metafísica, Vol. 49 (16), pp. 161-187.

69. Cf. Luxemburg, R., "Die Krise der Sozialdemokratie", op. cit., p. 62. Sobre el sentido que la disyuntiva "socialismo o barbarie" adquiere en el pensamiento de Luxemburg, cf. Löwy, M., On changing the world. Essays in Political Philosophy, from Karl Marx to Walter Benjamin, Haymarket, Chicago, 2013, pp. 91-99. 